\title{
Thermal history parameters drive changes in physiology and cold hardiness of young grapevine plants during winter
}

\author{
Francisco Gonzalez Antivilo ${ }^{\mathrm{a}, \mathrm{b}, *}$, Rosalía Cristina Paz ${ }^{\mathrm{c}}$, Mariela Echeverria ${ }^{\mathrm{d}}$, Markus Keller ${ }^{\mathrm{e}}$, \\ Jorge Tognetti ${ }^{\mathrm{f}, g}$, Roberto Borgo ${ }^{\mathrm{h}}$, Fidel Roig Juñent ${ }^{\mathrm{b}}$ \\ a INTA EEA-San Juan, Calle 11 y Vidart (5427), Villa Aberastain, San Juan, Argentina

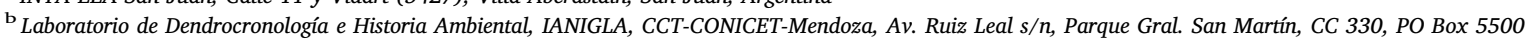 \\ Mendoza, Argentina \\ ${ }^{c}$ CIGEOBIO (FCEFyN, UNSJ/CONICET), Av. Ignacio de la Roza 590 (Oeste), J5402DCS, Rivadavia, San Juan, Argentina \\ d Conicet-Universidad Nacional de Buenos Aires, Instituto de Investigaciones en Biociencias Agrícolas y Ambientales (INBA), Buenos Aires, Argentina \\ e Department of Horticulture, Irrigated Agriculture Research and Extension Center, Washington State University, Prosser, WA 99350, USA \\ ${ }^{\mathrm{f}}$ Laboratorio de Fisiología Vegetal - Facultad de Ciencias Agrarias - Universidad Nacional de Mar del Plata, Buenos Aires, Argentina \\ ${ }^{g}$ Comisión de Investigaciones Científicas de la Provincia de Buenos Aires, Argentina \\ ${ }^{\text {h }}$ Cátedra de Fisiología Vegetal, Facultad de Ciencias Agrarias, Universidad Nacional de Cuyo, Almirante Brown 500, Luján de Cuyo, Mendoza, Argentina
}

A R T I C L E I N F O

\section{Keywords:}

Winter season

Acclimation

Deacclimation

Temperature

Vitis vinifera

Climate change

\begin{abstract}
A B S T R A C T
Vitis vinifera is mainly cultivated in temperate areas, where seasons are well defined and winter conditions might be severe. To survive under these conditions during the dormant season, grapevines sense environmental parameters to trigger different protective mechanisms that lead to cold hardiness (CH). Crop yield and sustainability will be determined according to the level of $\mathrm{CH}$ reached in each organ. Moreover, different cultivars of $V$. vinifera exhibit different behavior throughout the dormant season, attaining a different status of $\mathrm{CH}$. However, there is scarce information concerning how the same cultivar behaves under contrasting thermal environments. The aim of our research was to unveil how $\mathrm{CH}$ varies in trunks of the same cultivar under two contrasting environments and define which are the main thermal and biochemical parameters involved in this process. We submitted 2-year old plants of the same clone of cv. Malbec to two different thermal conditions: natural winter (control) and artificially warm winter (treatment). $\mathrm{CH}$ status, thermal and biochemical parameters in trunks were measured periodically over the dormant season, and this experiment was repeated for three years. Our results suggest that grapevine trunks subjected to a different environment reach dissimilar $\mathrm{CH}$ status, except at the end of winter. In addition, we determined that daily minimum temperature is the main thermal parameter that drives changes in $\mathrm{CH}$. Also, we found that the total soluble sugars have the greatest relative weight in determining the $\mathrm{CH}$ compared with the other compounds evaluated. These results have practical implications in the establishment of vineyards for new growing regions. Moreover, with rising minimum temperature predicted by climate change scenarios, grapevines may be more vulnerable to cold events during the dormant season.
\end{abstract}

\section{Introduction}

Vitis vinifera is a perennial liana adapted to temperate climates, capable of surviving to relatively low temperatures during the winter. The acquisition of dormancy and cold hardiness $(\mathrm{CH})$ is an active, dynamic and complex process with physiological-biochemical adaptations (Weiser, 1970; Shaulis, 1971; Chen and Li, 1977). Classically, the dormant period is divided into three stages: acclimation, characterized as a period of transition from the non-hardy to the fully hardy state; ii) mid-winter, characterized as a period of most severe cold and greatest $\mathrm{CH}$; and iii) deacclimation, characterized as a period of transition from the fully hardy to the non-hardy state and active growth (Howell, 2000; Ferguson et al., 2014). Traditionally it is thought that during midwinter $\mathrm{CH}$ reaches a threshold of maximum resistance, a factor that is considered constant and independent of weather, even if a warm event occurs (Proebsting et al., 1980; Zabadal et al., 2007; Beck et al., 2004). For that, $\mathrm{CH}$ had been described as a U-shaped curve with a maximum hardiness level MHL) thought to be as constant for each year

\footnotetext{
* Corresponding autor at: INTA EEA-San Juan, Calle 11 y Vidart (5427), Villa Aberastain, San Juan, Argentina.

E-mail address: ing.gonzalezantivilo@gmail.com (F. Gonzalez Antivilo).
} 
(Proebsting et al., 1980). CH is usually measured as the lethal temperature required to kill $50 \%$ of tissues $\left(\mathrm{LT}_{50}\right)$.

Surviving cold temperatures may involve different plant strategies, namely freezing tolerance and/or freezing avoidance, as defined by Levitt (1980). The avoidance of ice formation in plant tissues is linked to cryoprotective compounds that have the function of lowering the freezing point of the cytoplasm (supercooling). Some compounds that were reported to have cryoprotectant properties include simple soluble sugars and free amino acids (Pierquet and Stushnoff, 1980; Guy, 1990; Fennell, 2004). Moreover, tissue dehydration has also been cited as another mechanism to prevent ice formation. The other mechanism is freezing tolerance, which is the capacity to tolerate both ice in the apoplast and the high concentration of solutes in cells (Levitt, 1980).

Grapevine exploits both of these mechanisms. In buds the $\mathrm{CH}$ is based predominantly on supercooling but in woody tissues the two mechanisms occur simultaneously (Burke et al., 1976; Andrews et al., 1984; Badulescu and Ernst, 2006). The efficacy of these mechanisms depends on temperature, species, and cultivar in question, meaning that there is a genetic potential of CH (Keller, 2010). It has been reported that $V$. vinifera is not particularly cold hardy, suffering more freeze damage during winter compared with American grapevines species (Londo and Kovaleski, 2017).

Macroclimatic changes may affect local winter conditions. Mendoza Province (MZA), Argentina, between $32^{\circ}$ and $36^{\circ}$ South latitude, is the most important grapevine ( $V$. vinifera) production region in South America (almost 160,000 ha). Its macroclimate is dry and temperate with a high continentality due to the proximity of the Andes mountain range. This results in a large thermal amplitude over the day/night cycle and between different seasons (Gonzalez Antivilo et al., 2017). Moreover, during winter and spring a strong, dry and warm föhn wind called Zonda is common (Norte and Simonelli, 2016) and may be followed by freezing events that cause injury in fruit trees and reduce plant yields (Caretta et al., 2004).

MZA is a desert region with less than $200 \mathrm{~mm}$ /year of precipitation. Therefore, the crops are irrigated with water from melting snow in the Andes, which leads to the crops being concentrated in four small productive oases with different agroclimatic characteristics, partially defined by their geographic location as North, East, Central and South oases (Suppl Fig1A; González et al., 2009; DACC, 2013). More than 20 grapevine cultivars are grown in MZA. The most emblematic cultivar is Malbec which has experienced a strong increase in the last 15 years, more than doubling in the production area to reach 40,000 ha, and distributed in all oases (Instituto Nacional de Vitivicultura, INV, 2016).

According to the IPCC (Stocker et al., 2013) projections, a temperature increase between $2{ }^{\circ} \mathrm{C}$ and $4{ }^{\circ} \mathrm{C}$ for the next 100 years is expected worldwide. In MZA there has already been an increase in the average minimum winter temperature over the last 50 years (Deis et al., 2015). Other predictions also indicate that climate contingencies will be more extreme, including cold and heat wave events, and a longer frost-free period (Aruani, 2010). Plants will live in a riskier environment if it is fluctuating (Londo and Kovaleski, 2017). In the last decade, hard winters with very low absolute temperatures and late frosts were registered, affecting several production areas in MZA (DACC, 2013). For example, severe freezing events were recorded in large parts of the province, both during the dormant $\left(<-15^{\circ} \mathrm{C}\right)$ and growing $\left(<-4{ }^{\circ} \mathrm{C}\right)$ seasons during 2015 and 2016. By coincidence, the INV indicated grape harvest losses up to $30 \%$ for these seasons, compared with the previous harvests. Therefore, as cold injury affects both yield and vineyard sustainability, it is necessary to enhance local information to assist producers and government agencies in zoning existing cultivated areas by variety and in better matching varieties to specific zones at the time of planting a new vineyard.

The objective of this study was to determine if the CH status of $V$. vinifera can be affected by the thermal history during the dormant season. Our strategy consisted in subjecting plants to two contrasting thermal environmental and to evaluate the change in $\mathrm{CH}$ in order to establish the relationship between the process of acclimation-deacclimation and different thermal parameters. With this, we tried to establish which parameters explain this relationship better. Moreover, we wanted to unveil periods throughout the dormant season during which the thermal history can influence the maintenance of $\mathrm{CH}$. This information could be linked to agroecological characteristics of each production oases of MZA within the framework of climate change predictions. Finally, we measured the seasonal changes of different physiochemical parameters involved in cold acclimation in order to determine which one may be the most influential in this process.

\section{Materials and methods}

\subsection{Field experiments}

\subsubsection{Locations and plant material}

Three independent experiments were conducted during the winter season (June to September) of the years 2012, 2013, and 2016 (hereinafter referred to as Y-1, Y-2, and Y-3, respectively). During the first two years, assays were carried out in Luján de Cuyo $\left(33^{\circ} 35^{\prime} 24^{\prime \prime} \mathrm{S} ; 68^{\circ}\right.$ $30^{\prime} 00^{\prime \prime} \mathrm{W}$; $925 \mathrm{~m}$ asl), whereas in the third year, it was conducted in Godoy Cruz ( $32^{\circ} 55^{\prime} 6.69^{\prime \prime} \mathrm{S}$; 68 $50^{\prime} 32.82^{\prime \prime} \mathrm{O}$; $787 \mathrm{~m}$ asl), both located in the northern agricultural oases of MZA, Argentina.

For each experiment, 200 2-year-old, own-rooted Malbec certificated clone Perdriel plants were used. Plants were grown in 7-liter pots filled with a mixture of soil:sand:perlite (2:1:1 by vol). During the dormant season (autumn to winter), plants were watered every 15 days. During the growing season (end of winter and spring), at the start of bud burst, watering frequency was increased to twice a week. In order to maintain the canopy in healthy conditions standard pest control strategies were applied until the natural leaf fall. During the months prior to the application of thermal treatments (March to May), plants were grown outdoors.

\subsubsection{Thermal treatments, monitoring and ecological characterization}

At the beginning of the winter season, plants were randomly divided into 2 groups of 100 plants each. Each group was assigned to a different thermal treatment: natural winter $\left(\mathrm{W}_{\mathrm{N}}\right)$ and artificially warm winter $\left(\mathrm{W}_{\mathrm{W}}\right)$. The $\mathrm{W}_{\mathrm{N}}$ was considered as control, and consisted of maintaining plants under natural winter field conditions, whereas the $\mathrm{W}_{\mathrm{W}}$ treatment consisted of increasing the temperature by using a greenhouse and adding an external source of heat. During Y-1 and Y-2, a $1000 \mathrm{~W}$ electric fan heater installed $1 \mathrm{~m}$ above soil level was placed within a $2 \times 3 \mathrm{~m}$ greenhouse coated with 200-micron crystal polyethylene UV protection. In Y-3, a natural gas heater of $3000 \mathrm{cal} / \mathrm{hour}$ was placed $10 \mathrm{~cm}$ above the ground in a $3 \times 4 \mathrm{~m}$ greenhouse with the same coating. Heating was performed throughout every night (approximately from 8:00 PM to 7:00 AM of the next day). There were differences in the way heat was applied: i) in $\mathrm{Y}-1$, the electric heater was programmed to be turned on $30 \mathrm{~min}$ and turned off $30 \mathrm{~min}$ each hour; ii) in Y-2, the heater remained on for $2 \mathrm{~h}$ and off for $1 \mathrm{~h}$ per cycle; iii) the natural gas heater remained on all night long.

During Y-1 and Y-2, the temperature was monitored using iButton sensors (Thermochron DS1922L-F5 temperature loggers, Maxim Integrated, San Jose, CA, USA, with a measurement range of -40 to $+125^{\circ} \mathrm{C}$, and accuracy $\pm 0.5^{\circ} \mathrm{C}$ ); whereas during Y-3, an Arduino mega 2560 logger integrated with DS18B20 sensors developed by IANIGLA-CONICET was used after contrasting and checking with iButton. In all years, two sensors per treatment were installed.

In order to characterize and compare the ecological environments generated by treatments over grapevine physiology during the dormant season (from April 1 until August 31) of Y-1, Y-2 and Y-3, two ecological indices were calculated according to Deis et al (2015): i) $\Sigma T$ Tmin, corresponding to the summation of daily minimum temperature (Tmin) during the dormant season and ii) $n^{\circ} \mathrm{D}<-3$, corresponding to the total number of days that reached temperatures equal to or lower than 
$-3^{\circ} \mathrm{C}$. These indices were compared with historical records of different production oases in MZA.

\subsubsection{Non-destructive and destructive measurements}

Phenology was non-destructively assessed on 10 plants randomly selected and labeled specifically for this purpose. Phenological status was determined every 3 days from the beginning of the experiments (June), and classified into three stages according to the modified EL phenological system: dormant (Stage 1, closed or wintering bud), late bud swell (Stage 5, swollen bud or green tip) and bud burst (Stage 7 bud with expanded or budded first leaf). After bud burst, shoot length was measured at the same frequency for one month.

Destructive sampling was performed every 15 days, approximately, after the start of the experiment. At each sampling date, 8 plants per treatment were randomly selected for laboratory analysis (without replacement).

\subsection{Laboratory analysis}

\subsubsection{Sample processing}

In order to avoid sample warming that could lead to deacclimation, sampling collection was done at sunrise. Trunks were cut at soil level, discarding roots and any current-year shoot. Each trunk was placed in an airtight bag with a moist absorbent paper to avoid tissue dehydration. The bags were put in a Styrofoam box until the end of sampling and subsequent transportation to the laboratory.

In the laboratory, trunks were divided into three parts of $5-10 \mathrm{~cm}$ each, and used for a different analysis: i) the upper part (Section 1), was immediately frozen in liquid nitrogen and kept at $-20{ }^{\circ} \mathrm{C}$ until it was used to measure total free amino acids (TFA, measured only in Y-3;) ii) the middle portion (Section 2), was used to measure water content (WC), total soluble sugars content (TSS) and starch content and iii) the basal portion (Section 3) was used to measure $\mathrm{CH}$ status; Fig. 1 shows a schematic diagram of the sampling process.

\subsubsection{Controlled freezing simulation and $\mathrm{CH}$ status determination}

For freezing simulations, a commercial freezer Gafa model Eternity S120, controlled by a computer based on Arduino mega 2560 logger equipment was used. The temperature was allowed to decrease from ambient to $10{ }^{\circ} \mathrm{C}$. From this point, the temperature was lowered at $-2{ }^{\circ} \mathrm{C} / \mathrm{h}$ until reaching $-19{ }^{\circ} \mathrm{C}$. The temperature was monitored and recorded in real time with an integrated sensor DS18B20.

To measure $\mathrm{CH}$, the basal portion of each trunk was divided into 4 to $5 \mathrm{sub}$ portions of $\sim 3 \mathrm{~cm}$ each (Suppl Fig2a-b). All the fragments obtained from the same treatment were mixed, to make a composite sample (SupplFig2c). Then, 10 packages with 5 pieces of trunk each were assembled per treatment and wrapped in aluminum foil. Each package was assigned to a final freezing temperature: Control (not freezing), $-2,-4,-6,-8,-10,-12,-14,-16,-18^{\circ} \mathrm{C}$. The packages were removed as simulated freezing progressed (SupplFig2d-e). Upon removal the samples were placed in darkness at $7{ }^{\circ} \mathrm{C}$ for $24 \mathrm{~h}$ then at room temperature $\left(\sim 20^{\circ} \mathrm{C}\right)$ for another $24 \mathrm{~h}$ (SupplFig2h).

The death of phloem and xylem tissues was visually assessed by the browning method, which has been shown to be highly correlated with lethal temperatures determined by differential thermal analysis (Mills et al., 2006). This method is currently a standard procedure to determine CH status in trunks (Aslamarz et al., 2010; Moran et al., 2011). Trunk fragments were transversally cut in halves, then phloem and xylem tissues were observed under a stereomicroscope and classified as alive or dead according to their visual appearance (SupplFig2h-i). The method to estimate $\mathrm{LT}_{50}$ in both tissues is described below, in "Statistical analysis" section.

\subsubsection{Water content}

Fresh weight (FW) was determined using wood material from Section 2 of trunks (Fig. 1) with a precision balance with an accuracy of

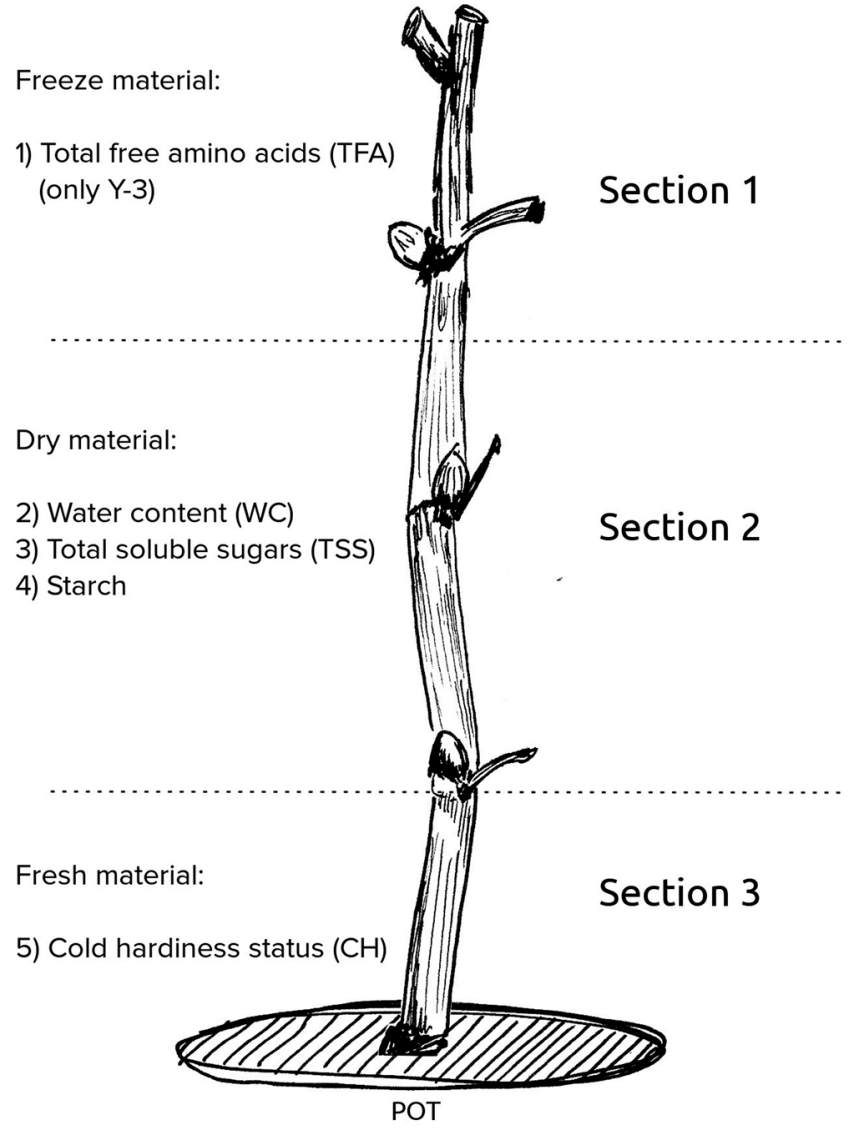

Also

6) Phenology

Treatments

a) Natural winter (Control)

b) Artificially warm winter

Fig. 1. Trunk sections of two-year-old Vitis vinifera plants. Plants maintained under natural winter conditions $\left(\mathrm{W}_{\mathrm{N}}\right)$ or artificially warm winter $\left(\mathrm{W}_{\mathrm{W}}\right)$ conditions were sectioned into three parts for different analyses: i) Section 1, determination of total free amino acids (TFA); ii) Section 2, determination of total soluble sugar (TSS), starch and water (WC) contents; iii) Section 3, evaluation of cold hardiness $(\mathrm{CH})$ status.

$0.1 \mathrm{mg}$. Then, sections were oven-dried at $60{ }^{\circ} \mathrm{C}$ for $48 \mathrm{~h}$. Samples were weighed again to determine dry weight (DW). Water content was calculated as follows $\mathrm{WC}=(\mathrm{FW}-\mathrm{DW}) \times 100 \times \mathrm{FW}^{-1}$.

\subsubsection{Total soluble sugars and starch content}

After determining WC, dry trunk portions of Section 2 were ground with a bladed mill Retsch Z200 (Haan, Germany) to a particle size of $<0.08 \mathrm{~mm}$. Total soluble sugars (TSS) were extracted with $80 \%$ ethanol during $45 \mathrm{~min}$. The supernatant was centrifuged at $10,000 \mathrm{rpm}$ for $5 \mathrm{~min}$. Sugars were quantified using the anthrone method (Yemm and Willis, 1954). The pellet was resuspended, digested with perchloric acid, and starch was quantified by spectrophotometry as described by McCready et al. (1950).

\subsubsection{Total free amino acids}

Total free amino acids (TFA) were determined from Section 1 of trunk as described above. Trunk portions were powdered in a mortar 
with the addition of liquid nitrogen to avoid thawing of the samples. TFA content was determined spectrophotometrically by the ninhydrin method described by Yemm and Cocking (1955).

\subsection{Statistical analysis}

For comparison of thermal parameters among years and treatments, mean values of mean temperature (Tmean), minimum temperature (Tmin), maximum temperature (Tmax) and thermal amplitude (TA) were calculated using daily records during the winter season of years $\mathrm{Y}$ $1, \mathrm{Y}-2$ and Y-3 $(\mathrm{n}=90$ days per year). For the analysis of differences between thermal parameters, one way-ANOVA was used. When effects were significant, multiple comparisons were performed using DGC method with $\alpha=0.05$ (Di Rienzo et al., 2002).

For the $\mathrm{LT}_{50}$ analysis in phloem and xylem $\left(\mathrm{LT}_{50-\mathrm{P}}\right.$ and $\mathrm{LT}_{50-\mathrm{x}}$, respectively) each trunk was recorded as 'alive' or 'dead' (binary family). Then, the proportion of dead tissues ( $\mathrm{P}_{\text {Pdead }}$ and $\mathrm{P}_{\mathrm{Xdead}}$ for phloem and xylem respectively) was calculated for each freezing dose temperature and winter thermal treatment $(n=5$; SupplFig2h-i). Adjusted curves of damage proportion were obtained using a logistic regression by generalized linear mixed model (GLMM; co variable: freezing temperature dose; fixed effects: temperature treatment) in each year. The statistical comparison was made between curves, and effects were considered significant if $\mathrm{p}<0.05$. The $\mathrm{LT}_{50-\mathrm{P}}$ and $\mathrm{LT}_{50-\mathrm{x}}$ were obtained using the equation $\pi=(\exp (\eta)) /(1+\exp (\eta))$, where $\eta$ is the proportion of dead tissue. The relationship between thermal history and $\mathrm{LT}_{50-\mathrm{P}}$ and $\mathrm{LT}_{50-\mathrm{x}}$ was tested using Pearson's correlation analysis. For this, the mean values of Tmax, Tmin, Tmean and TA were used considering the records of $1,3,5,10$ and 15 days prior to the simulated freezing event. In the same way, a Pearson correlation between $\mathrm{CH}$ and WC was also performed. In this case, data were partitioned into two parts, one of them including only those data that showed statistically significant differences between treatments in $\mathrm{CH}$, and the other one including only those data without differences among treatments in $\mathrm{CH}$. In both cases, correlations were considered significant at $\mathrm{p}<0.05$. For biochemical parameters, curves of changes in TSS, starch and TFA were made using mean values and standard deviation $(n=8)$. In order to compare the effect of treatment over these curves, a generalized linear model (GLM; co variable: time; fixed effects: treatment, sampling and interaction) was used. This model estimates statistical differences between curves ( $\mathrm{p}<0.05$ ). The analyses were partitioned by year.

Principal Component Analysis was performed, including three years of measurements of thermal (Tmax, Tmin), physiological ( $\mathrm{LT}_{50-\mathrm{P}}$ and $\mathrm{LT}_{50-\mathrm{X}}$ ) and biochemical (WC, TSS, starch) variables potentially associated with $\mathrm{CH}$. Also, a MANOVA was done, and when significant, a mean comparison was conducted by the Hotelling test, and differences were considered significant if $\mathrm{p}<0.05$. All the analyses were done using Infostat v 2017 (Di Rienzo et al., 2017).

\section{Results}

\subsection{Thermal characteristics of natural and artificial warming treatments}

Two contrasting environments were generated with the $\mathrm{W}_{\mathrm{N}}$ and $\mathrm{W}_{\mathrm{W}}$ treatments during each winter season of the three analyzed years (Table1). Differences were significant in almost all the thermal variables and years analyzed. The differences between thermal treatments ranged from 3.3 to $5.1{ }^{\circ} \mathrm{C}$ for Tmean, $13.0-13.4^{\circ} \mathrm{C}$ for Tmax, $0.6-2.6^{\circ} \mathrm{C}$ for Tmin, and $10.5-12.7^{\circ} \mathrm{C}$ during the three years. Inter-annual differences among $\mathrm{W}_{\mathrm{N}}$ were also observed, mainly with respect to Tmin variation. Whereas Y-2 was the coldest year, Y-3 was the warmest and Y-1 showed an intermediate behavior (Fig. 2, Table1, SupplFig3a-b). In Y-1 there was no significant difference in the average Tmin between treatments, in Y-2 the difference was $1.9{ }^{\circ} \mathrm{C}$ and in Y-3 it was $2.6{ }^{\circ} \mathrm{C}$. On the other hand, the difference of average Tmax between $\mathrm{W}_{\mathrm{N}}$ and $\mathrm{W}_{\mathrm{W}}$ was constant in the three years $\left(13-14^{\circ} \mathrm{C}\right)$.
Table 1

Thermal parameters comparison during the winter season between two contrasting thermal environments: natural winter $\left(\mathrm{W}_{\mathrm{N}}\right)$ and artificially warm winter $\left(\mathrm{W}_{\mathrm{W}}\right)$. Mean values of mean temperature (Tmean; A), minimum temperature (Tmin; B), maximum temperature (Tmax; C) and thermal amplitude (TA; D) were calculated using daily records during the winter season of the years 2012 (Y-1), 2013 (Y-2) and 2016 (Y-3). ns indicate non-significant differences. Different letters within columns indicate statistical differences between the years.

\begin{tabular}{|c|c|c|c|}
\hline \multirow{3}{*}{$\begin{array}{l}\text { A) } \\
\text { Year }\end{array}$} & \multicolumn{3}{|c|}{ Tmean $\left({ }^{\circ} \mathrm{C}\right)$} \\
\hline & \multicolumn{2}{|c|}{ Treatment } & \multirow[b]{2}{*}{$\mathrm{p}$} \\
\hline & $\mathrm{W}_{\mathrm{N}}$ & $\mathrm{W}_{\mathrm{W}}$ & \\
\hline $\mathrm{Y}-1$ & $9.1 \pm 0.4^{b}$ & $12.4 \pm 0.4^{b}$ & $<0.0001$ \\
\hline $\mathrm{Y}-2$ & $7.4 \pm 0.4^{c}$ & $11.9 \pm 0.4^{b}$ & $<0.0001$ \\
\hline $\mathrm{Y}-3$ & $11.2 \pm 0.4^{\mathrm{a}}$ & $16.3 \pm 0.4^{\mathrm{a}}$ & $<0.0001$ \\
\hline \multirow[t]{2}{*}{ B) } & \multicolumn{3}{|c|}{$\operatorname{Tmin}\left({ }^{\circ} \mathrm{C}\right)$} \\
\hline & \multicolumn{2}{|c|}{ Treatment } & \\
\hline Year & $\mathrm{W}_{\mathrm{N}}$ & $\mathrm{W}_{\mathrm{W}}$ & $\mathrm{p}$ \\
\hline Y-1 & $1.8 \pm 0.3^{b}$ & $2.4 \pm 0.3^{b}$ & $n s$ \\
\hline $\mathrm{Y}-2$ & $0.3 \pm 0.3^{c}$ & $2.2 \pm 0.3^{b}$ & $<0.0001$ \\
\hline $\mathrm{Y}-3$ & $6.1 \pm 0.3^{\mathrm{a}}$ & $8.7 \pm 0.3^{a}$ & $<0.0001$ \\
\hline \multirow[t]{2}{*}{ C) } & \multicolumn{3}{|c|}{$\operatorname{Tmax}\left({ }^{\circ} \mathrm{C}\right)$} \\
\hline & \multicolumn{2}{|c|}{ Treatment } & \\
\hline Year & $\mathrm{W}_{\mathrm{N}}$ & $\mathrm{W}_{\mathrm{W}}$ & $\mathrm{p}$ \\
\hline Y-1 & $20.0 \pm 0.6^{\mathrm{a}}$ & $33.4 \pm 0.8^{\mathrm{a}}$ & $<0.0001$ \\
\hline $\mathrm{Y}-2$ & $17.0 \pm 0.6^{b}$ & $30.0 \pm 0.8^{b}$ & $<0.0001$ \\
\hline $\mathrm{Y}-3$ & $16.7 \pm 0.6^{b}$ & $31.0 \pm 0.8^{b}$ & $<0.0001$ \\
\hline \multirow[t]{2}{*}{ D) } & \multicolumn{3}{|c|}{$\mathrm{TA}\left({ }^{\circ} \mathrm{C}\right)$} \\
\hline & \multicolumn{2}{|c|}{ Treatment } & \\
\hline \multirow[t]{4}{*}{ Year } & $\mathrm{W}_{\mathrm{N}}$ & $\mathrm{W}_{\mathrm{W}}$ & $\mathrm{p}$ \\
\hline & $18.3 \pm 0.5^{a}$ & $31.0 \pm 0.8^{\mathrm{a}}$ & $<0.0001$ \\
\hline & $17.4 \pm 0.5^{\mathrm{a}}$ & $27.9 \pm 0.8^{b}$ & $<0.0001$ \\
\hline & $10.5 \pm 0.5^{b}$ & $22.3 \pm 0.8^{c}$ & $<0.0001$ \\
\hline
\end{tabular}

\subsection{Ecological indices}

There were differences in $\Sigma$ Tmin between $\mathrm{W}_{\mathrm{N}}$ and $\mathrm{W}_{\mathrm{W}}$ in all years. The modified thermal environment $\left(\mathrm{W}_{\mathrm{W}}\right)$ increased values of this index (SupplFig1c) by 20, 130 and $33 \%$ for Y-1, Y-2 and Y-3 respectively. Under $\mathrm{W}_{\mathrm{N}}, \Sigma \mathrm{Tmin}$ was much higher in $\mathrm{Y}-1\left(422^{\circ} \mathrm{C}\right)$ than in $\mathrm{Y}-2\left(214^{\circ} \mathrm{C}\right)$. Conversely, $\mathrm{W}_{\mathrm{W}}$ recorded very similar index values $\left(\Sigma \mathrm{Tmin}: 516^{\circ} \mathrm{C}\right.$ and $499^{\circ} \mathrm{C}$ in $\mathrm{Y}-1$ and $\mathrm{Y}-2$ respectively). In Y-3, in which the experiment was conducted in a warmer location, $\Sigma$ Tmin was much higher in both treatments $\left(\mathrm{W}_{\mathrm{N}}=912{ }^{\circ} \mathrm{C}\right.$ and $\left.\mathrm{W}_{\mathrm{W}}=1214^{\circ} \mathrm{C}\right)$. No differences were observed in $n^{\circ} \mathrm{D}<-3$ between thermal treatments in $\mathrm{Y}-1$ and $\mathrm{Y}-3$. However, the interannual variation was very marked between these two years ( $\mathrm{n}^{\circ} \mathrm{D}<-3=15$ and 0 respectively). Conversely, Y-2 was the most contrasting: there were nearly 3 times more days with temperatures below $-3^{\circ} \mathrm{C}$ in $\mathrm{W}_{\mathrm{N}}$ than in $\mathrm{W}_{\mathrm{W}}$.

\subsection{Phenology}

In the 3 years of measurement vines in the $\mathrm{W}_{\mathrm{W}}$ treatment were the first to burst each spring, but the timing varied among years. In the warmer year (Y-3) the difference in bud burst time between thermal treatments was more than 30 days, whereas it was only 17 days in the coldest year (Y-2). In Y-1, plants showed an intermediate behavior (Table2). 


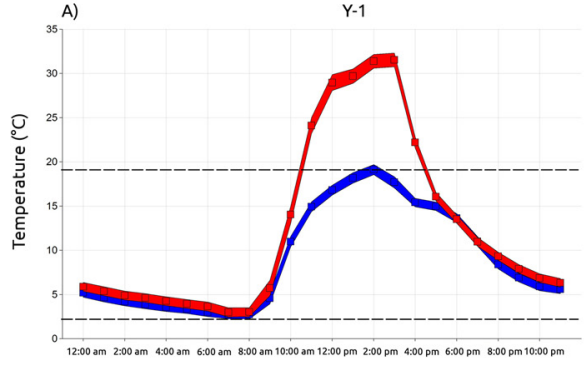

Hour

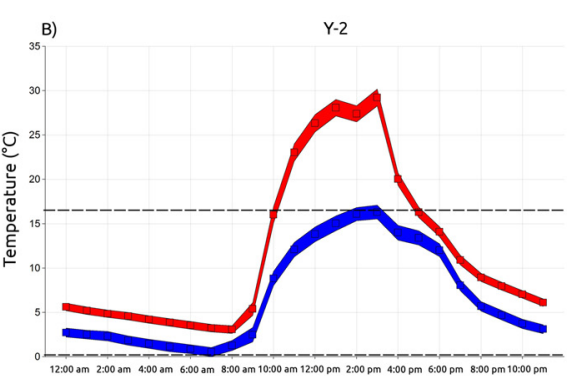

Hour

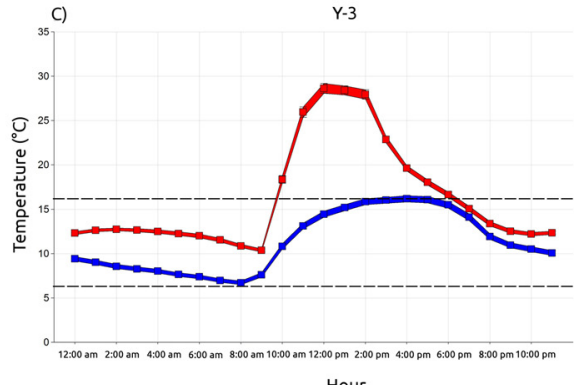

Hour

Fig. 2. Daily thermal environment comparison between natural winter conditions $\left(\mathrm{W}_{\mathrm{N}}\right.$; blue line) and artificially warm winter $\left(\mathrm{W}_{\mathrm{W}}\right.$; red line). Tmax and Tmin were registered hourly during the 3-month winter season in 2012 (Y-1; A), 2013 (Y-2; B) and 2016 (Y-3; C). The thickness of the line denotes temperature variability between winter days (For interpretation of the references to colour in this figure legend, the reader is referred to the web version of this article).

Table 2

Beginning of bud burst (Stage 7 according EL system) in Vitis vinifera subjecting under two contrasting thermal environments during three winters, 2012, 2013 and 2016 (Y-1, Y-2, Y-3 respectively): natural winter conditions $\left(\mathrm{W}_{\mathrm{N}}\right)$ and artificially warm winter $\left(\mathrm{W}_{\mathrm{W}}\right)$.

Stage 7: bud burst

\begin{tabular}{llll}
\cline { 2 - 4 } Year & $\mathrm{W}_{\mathrm{N}}$ & $\mathrm{W}_{\mathrm{W}}$ & Diff (days) \\
\hline Y-1 & Sept-17 & Aug-24 & 24 \\
Y-2 & Sept-12 & Aug-26 & 17 \\
Y-3 & Aug- 12 & Jul-11 & 32 \\
\hline
\end{tabular}

\subsection{Winter $\mathrm{CH}$ of trunk phloem and xylem from plants with different} thermal history

\subsubsection{CH status}

A similar pattern was observed across years in $\mathrm{CH}$ of trunk phloem (measured as $\mathrm{LT}_{50-\mathrm{P}}$ ) throughout the winter, with significant differences among sampling dates and treatments (Table3, SupplFig3c, SupplFig4). During early- and mid- winter significant differences were observed in phloem $\mathrm{CH}$ between $\mathrm{W}_{\mathrm{N}}$ and $\mathrm{W}_{\mathrm{W}}\left(\mathrm{LT}_{50-\mathrm{p}}\right.$ ranges in all years were -16.5 to $-12.1{ }^{\circ} \mathrm{C}$, and -14.5 to $-8.2{ }^{\circ} \mathrm{C}$ for $\mathrm{W}_{\mathrm{N}}$ and $\mathrm{W}_{\mathrm{W}}$ treatments, respectively). Plants grown under warm conditions were less resistant to cold than those grown under natural conditions (Table 3a). This difference disappeared about one month before the beginning of spring. In addition, the climatic conditions of each year also appeared to affect phloem $\mathrm{CH}$. Thus, Y-2 (the coldest year) was associated with lowest $\mathrm{LT}_{50-\mathrm{P}}$, whereas in Y-3 (the warmest year) the highest $\mathrm{LT}_{50-\mathrm{P}}$ values were reached (Table $3 \mathrm{a})$.

Results of $\mathrm{LT}_{50}$ in xylem are less clear than those observed in phloem (Table 3b, SupplFig3; SupplFig5). In several cases, cold hardiness exceeded the range of temperatures tested in the freezing simulation (Table $3 b$ ). In any case, xylem was more cold hardy than phloem (range of $\mathrm{LT}_{50-\mathrm{x}}$ : $-13,3$ down to $<-19.0^{\circ} \mathrm{C}$ ). Moreover, the difference between treatments disappeared later in xylem than in phloem, lasting up to the beginning of spring (Table $3 \mathrm{~b}$ ).

\subsubsection{Thermal parameters and their correlations with $\mathrm{CH}$}

In order to explore how the thermal history influences the cold resistance of the trunk correlations between $\mathrm{CH}\left(\mathrm{LT}_{50-\mathrm{P}}\right.$ and $\left.\mathrm{LT}_{50-\mathrm{x}}\right)$ and the averages of Tmin, Tmax, TA and Tmean of 5 periods prior to the freezing simulation ( 1 day, 3 days, 5 days, 10 days and 15 days) were calculated (Fig. 3). These correlations were significant in both tissues and always positive, indicating that lower temperatures were associated with hardier trunk tissues, independent of the number of days used for the analysis. However, the correlation coefficient increased as more days were considered in the analysis in both tissues. The variation in Tmin explained more of the variation in $\mathrm{CH}$ status than did that in
Table 3

Three-years measurement of lethal temperature $\left(\mathrm{LT}_{50}\right)$ induced by thermal treatment $\left(\mathrm{W}_{\mathrm{N}}\right.$ and $\left.\mathrm{W}_{\mathrm{W}}\right)$ on phloem $\left(\mathrm{LT}_{50-\mathrm{P}}\right)$ and xylem $\left(\mathrm{LT}_{50-\mathrm{X}}\right)$ of Vitis vinifera during the winter season (2012 as Y-1, 2013 as Y-2 and 2016 as Y-3).

\begin{tabular}{|c|c|c|c|c|c|}
\hline & & LT50 P & $\mathrm{m}\left({ }^{\circ} \mathrm{C}\right)$ & & \\
\hline Year & Date & $\mathrm{p}$ & $\mathrm{N}_{\mathrm{W}}$ & $\mathrm{W}_{\mathrm{W}}$ & Diff \\
\hline 1 & August-2 & $*$ & -12.4 & -10.8 & 1.6 \\
\hline & August-18 & * & -14.4 & $\overline{-11.9}$ & 2.5 \\
\hline & September-11 & $n s$ & -8.5 & -8.0 & 0.5 \\
\hline 2 & June-25 & $*$ & -14.0 & -12.0 & 2.0 \\
\hline & July-16 & * & -16.4 & -14.5 & 1.9 \\
\hline & August-10 & * & -16.5 & -11.2 & 5.2 \\
\hline & August-31 & $n s$ & -13.1 & -12.0 & 1.1 \\
\hline & September-18 & $n s$ & -12.3 & -11.9 & 0.4 \\
\hline 3 & June-24 & $*$ & -16.3 & -9.2 & 7.0 \\
\hline & July-18 & * & -12.1 & -8.2 & 3.9 \\
\hline & August-8 & $*$ & -12.3 & -9.2 & 3.1 \\
\hline & August-28 & $n s$ & -9.3 & -7.0 & 2.3 \\
\hline & September-13 & $n s$ & -10.5 & -10.5 & 0.0 \\
\hline B & & & & & \\
\hline & & LT50 X & $\mathrm{n}\left({ }^{\circ} \mathrm{C}\right)$ & & \\
\hline Year & Date & $\mathrm{p}$ & $\mathrm{N}_{\mathrm{W}}$ & $\mathrm{W}_{\mathrm{W}}$ & Diff \\
\hline 1 & August-2 & $n s$ & -18.8 & -17.5 & 1.3 \\
\hline & August-18 & * & -19.6 & -15.6 & 4.0 \\
\hline & September-11 & $n s$ & $\overline{-13.8}$ & -12.8 & 1.0 \\
\hline 2 & June-25 & $n s$ & -18.3 & -16.1 & 2.2 \\
\hline & July-16 & nd & $<-19.0$ & -16.6 & $<2.4$ \\
\hline & August-10 & $*$ & -18.8 & -16.1 & 2.7 \\
\hline & August-31 & * & -18.8 & -15.5 & 3.3 \\
\hline & September-18 & $n s$ & -15.2 & -13.6 & 1.6 \\
\hline 3 & June-24 & nd & $<-19.0$ & -15.0 & $<4.0$ \\
\hline & July-18 & $*$ & -17.5 & -11.5 & 6.0 \\
\hline & August-8 & * & -17.7 & $\overline{-13.9}$ & 3.8 \\
\hline & August-28 & $*$ & -17.2 & -12.6 & 4.5 \\
\hline & September-13 & $n s$ & -13.3 & -12.5 & 0.8 \\
\hline
\end{tabular}

$n d$ : non determined; $n s$ : non significant; *: significant differences (for significance values, see SupplFig4 and SupplFig5); Diff means the difference between $\mathrm{LT}_{50}$ artificially warm winter $\left(\mathrm{W}_{\mathrm{w}}\right)$ and $\mathrm{LT}_{50}$ natural winter $\left(\mathrm{W}_{\mathrm{N}}\right)$.

Tmax. Other variables such as TA and Tmean were not correlated with $\mathrm{CH}$ status under our conditions (data not shown).

\subsection{Physiological and biochemical variables}

Plants in $W_{N}$ always had higher TSS than in $W_{W}$ (Fig. 4), despite large variation in $\mathrm{W}_{\mathrm{N}}$ and $\mathrm{W}_{\mathrm{W}}$ conditions among years. Sugars decreased when plants entered into the bud burst phase. Moreover, the effect of thermal treatment on sugar content became not significant when plants began to deacclimate in late winter and start of spring, 

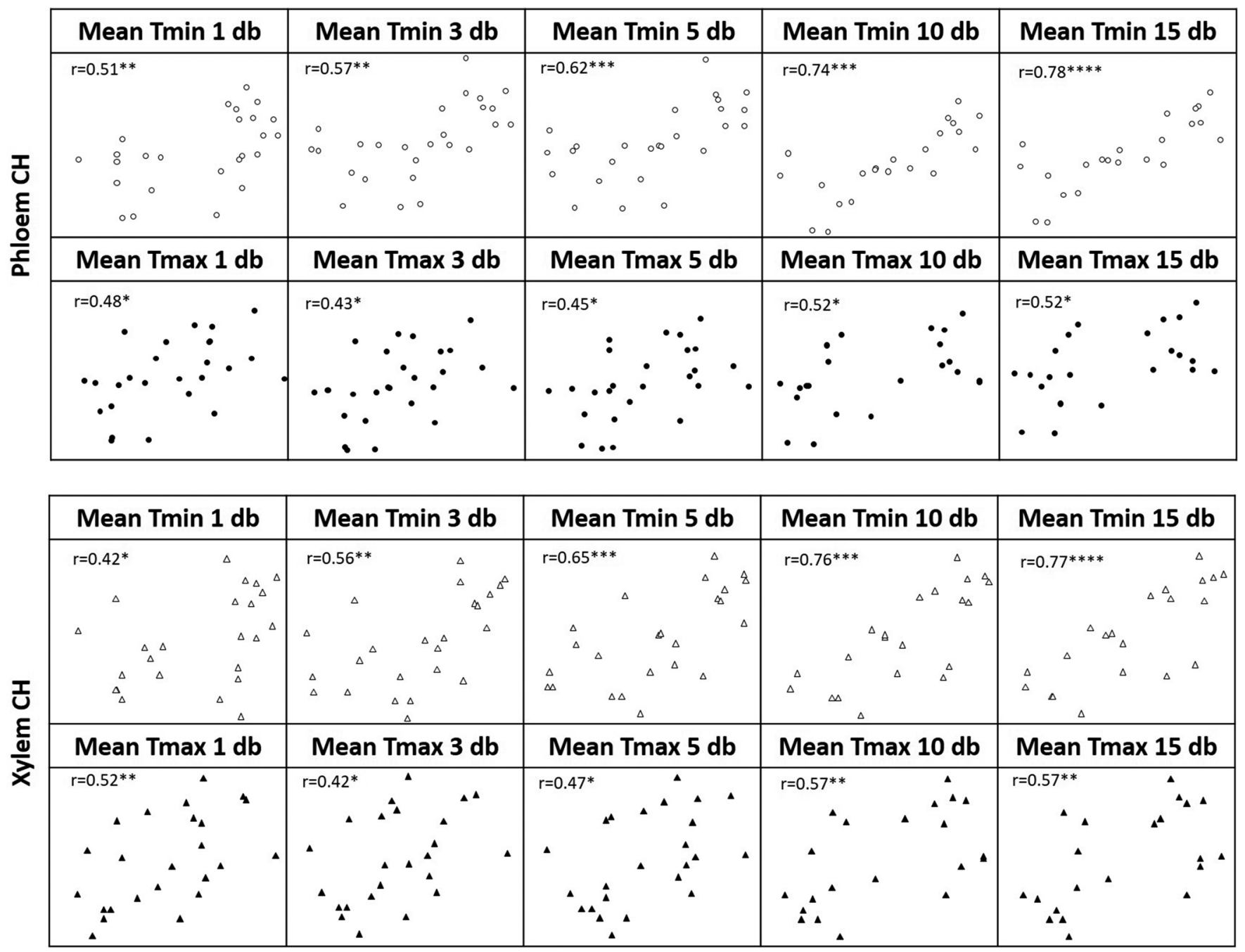

Fig. 3. Correlation analysis of the mean Tmax and Tmin registered at 1, 3, 5, 10 and 15 days prior to the measurement of the cold hardiness status in trunk phloem (A) and xylem tissues (B). Analysis was performed over three years during the winter season ( $\mathrm{n}=3$ years; 2012, 2013 and 2016). The number of asterisks indicates the significance level of correlation analysis: *, p $<0.05 ; * *, p<0.01 ;{ }^{* * *}, \mathrm{p}<0.0001$ and ${ }^{* * * *} \mathrm{p}<0.00001$.

approximately from September 22 (Fig. 4).

In Y-1 and Y-2, bud burst occurred at a stage in which $\mathrm{CH}$ was not significantly different between treatments (Fig. 4a-b). The Y-3 was the only one that presented significant differences in sugars even though the buds had already begun bursting (Fig. 4c).

In contrast with TSS, there was no correlation between starch and $\mathrm{CH}$ status (data not shown). The starch concentration varied between 6 and $13 \%$ during the analyzed period. The effects of thermal treatments on trunk starch were inconsistent and generally not significant.

Total free amino acid content (TFA) was only analyzed in Y-3. Under $\mathrm{W}_{\mathrm{N}}$ conditions, TFA concentrations remained virtually constant throughout the analyzed period (SupplFig6). On the other hand, in $\mathrm{W}_{\mathrm{W}}$ the TFA declined almost five-fold during bud burst. No clear relationship was found between amino acids, $\mathrm{CH}$ and the thermal history.

\subsection{Principal components analysis (PCA)}

In order to determine the importance of each one of the evaluated variables for the $\mathrm{CH}$ status of vines exposed to different thermal histories, we performed a PCA (Fig. 5) of the entire dataset. The 1st and 2nd canonical components explained together $67.5 \%$ of the total variation. The largest variation was explained by component 1 (51.9\%), where the canonical variables of $\mathrm{W}_{\mathrm{N}}$ (left quadrant; white symbols) and $\mathrm{W}_{\mathrm{W}}$ (right quadrant; black symbols) were mainly separated. The TSS was strongly associated with $\mathrm{W}_{\mathrm{N}}$ and exhibited a strong negative correlation with Tmin. The $\mathrm{CH}$ in phloem $\left(\mathrm{LT}_{50-\mathrm{P}}\right)$ and xylem $\left(\mathrm{LT}_{50-\mathrm{x}}\right)$ was associated with the thermal history; higher Tmax or Tmin values (thermal history of 10 days) were associated with less negative $\mathrm{LT}_{50}$ values. Component 2 , on the other hand, accounted for only $15.4 \%$ of the variation, and starch varied along this axis, which exhibited low association with $\mathrm{CH}$. Water content was partially related to the $\mathrm{W}_{\mathrm{W}}$ treatment, indicating that the higher the WC, the lower the degree of cold acclimation. The MANOVA indicates that thermal treatments were significantly different.

\section{Discussion}

\subsection{Cold hardiness status and its relationship with thermal history}

One of the patterns that describe $\mathrm{CH}$ status during the dormant season is the typical U-shaped curve (Proebsting et al., 1980). Currently, the real-time monitoring system of $\mathrm{CH}$ status carried out by Washington State University confirms that sort of curve in different $V$. vinifera varieties (http://wine.wsu.edu/extension/weather/coldhardiness/). Most of this research has been performed in sites exposed to a low TA and where sometimes extreme Tmin conditions occur (Proebsting et al., 1980; Mills et al., 2006; Cragin et al., 2017). However, there are other studies that support the notion that $\mathrm{CH}$ fluctuates 
A)

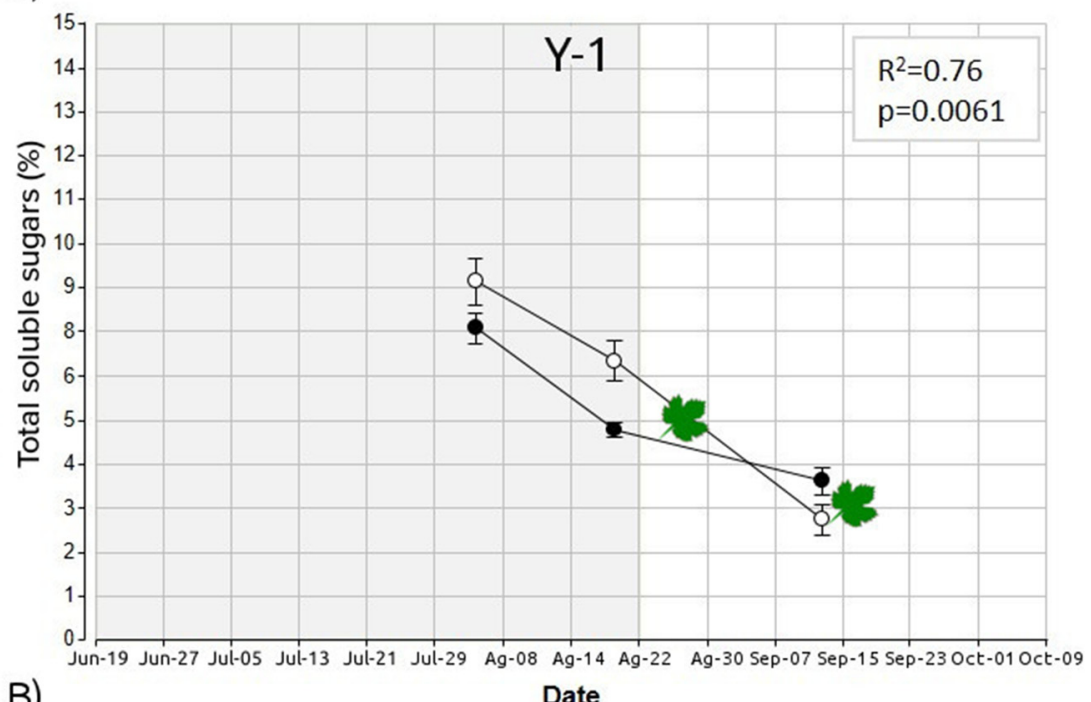

B)

Date
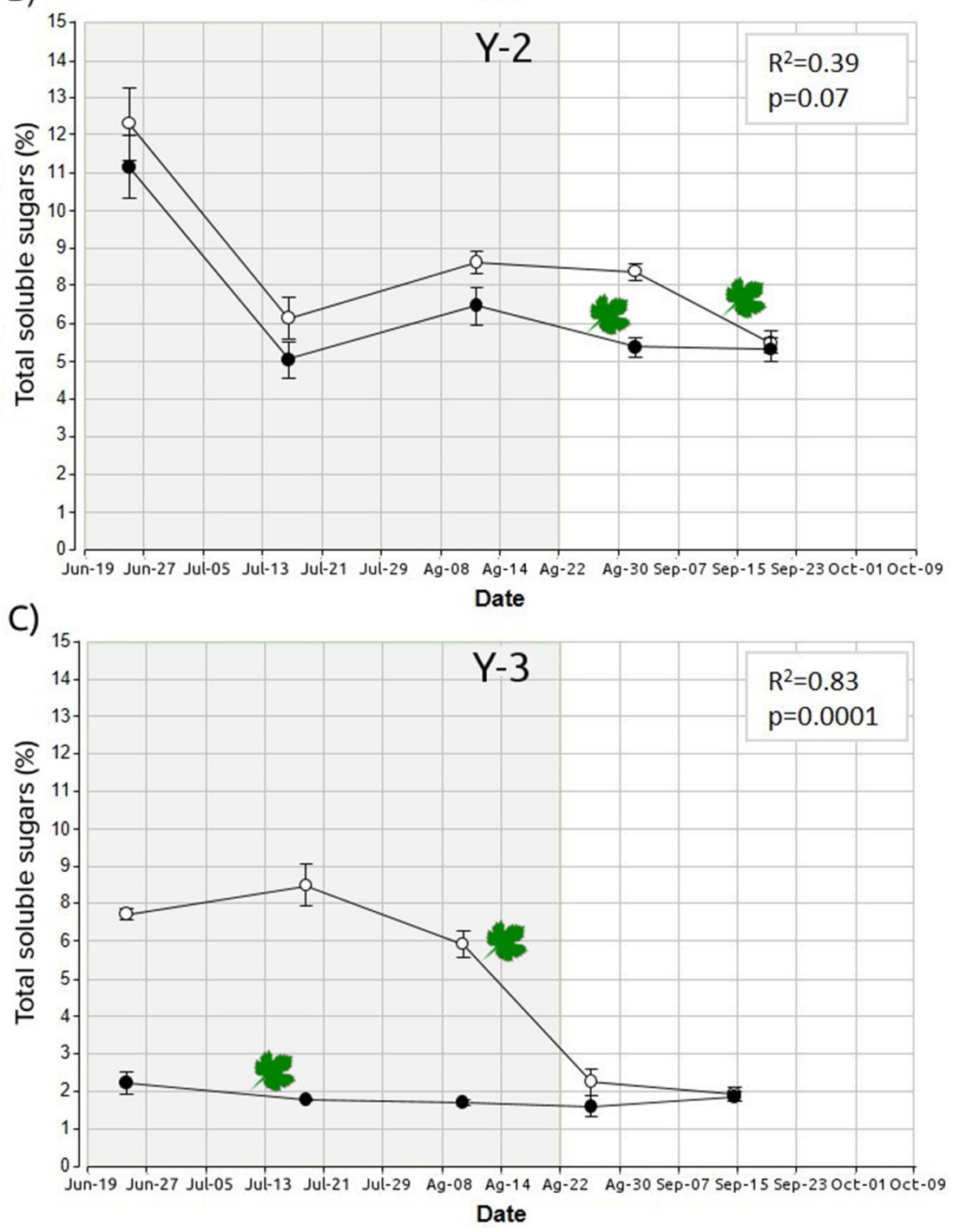

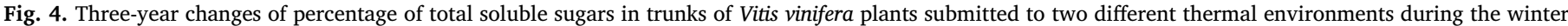

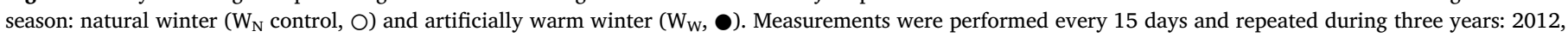

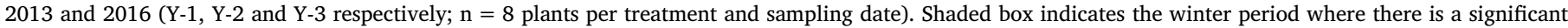
effect of temperature on cold hardiness. Leaves indicate the beginning of bud burst in each treatment. 


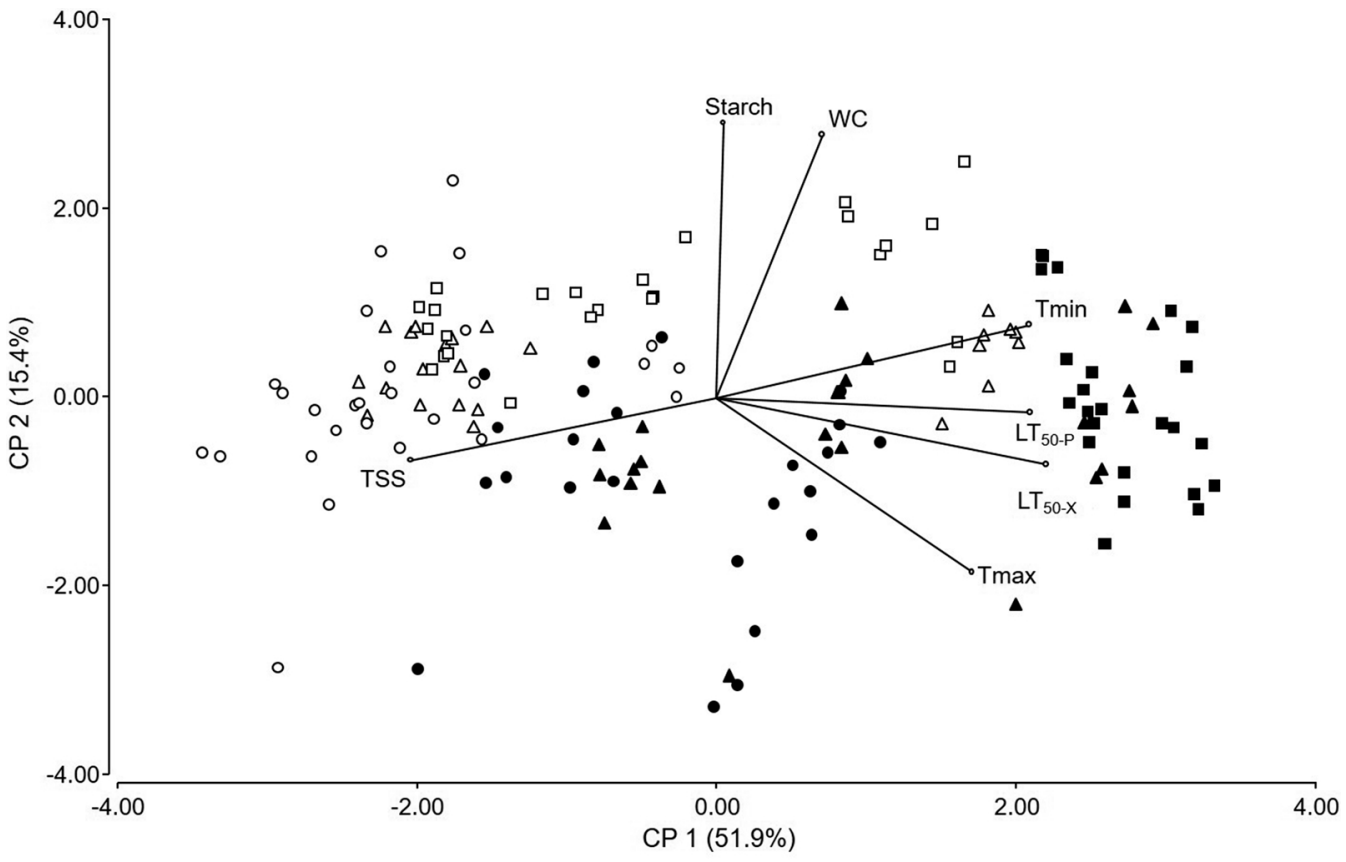

Significant Roy MANOVA test $(p<0.0001)$. Means comparis on by Hotelling's test.

\begin{tabular}{cccccccccc}
\hline Treatment & WC & TSS & Starch & PLT50 & XLT50 & Tmin & Tmax & $\mathbf{n}$ & \\
\hline $\mathbf{W}_{\mathbf{N}}$ & 47.6 & 6.7 & 10 & -13.1 & -17.7 & 2.2 & 17.1 & 76 & $\mathrm{~A}$ \\
$\mathbf{W}_{\mathbf{W}}$ & 47 & 4.9 & 9.1 & -10.5 & -14.8 & 4.6 & 31.2 & 73 & $\mathrm{~B}$ \\
\hline
\end{tabular}

Means with different letter has significant differences $(p<0.05)$
Fig. 5. Principal Component Analysis (PCA) including three years of measurement of thermal (Tmin and Tmax), physiological $\left(\mathrm{LT}_{50-\mathrm{P}}\right.$ and $\mathrm{LT}_{50-\mathrm{x}}$ ) and biochemical variables (starch, total soluble sugars or TSS, and water content or WC) involved in cold hardiness of $V$. vinifera. White symbols correspond to $\mathrm{W}_{\mathrm{N}}$ (Y1- $\triangle$; Y2- $\square$; Y3-O) and black symbols to $\mathrm{W}_{\mathrm{W}}$ (Y1-^; Y2- $\square$; Y3-O) treatments. Table below PCA shows MANOVA results followed by means comparisons by Hotelling test. Different letters indicate differences among treatments $(\mathrm{p}<0.05)$. depending on the thermal conditions of the season every year (Hubácková, 1996; Vitra et al., 2017). In addition, maximum CH may not be automatically reached in every year, but may rather depend on the thermal history to which grapevine is subjected, which may or may not allow reaching the full genetic potential of each cultivar (Schnabel and Wample, 1978; Fennell and Hoover, 1991; Moran et al., 2011; Londo and Kovaleski, 2017). In the 3 years measured in the present work, there were differences in $\mathrm{CH}$ that could be explained as a function of the thermal history, where the coldest year recorded the greatest resistance and the warmest year the least (Table 3; SupplFig3).

We subjected young plants of the same clone of $V$. vinifera to two different thermal environments, controlling the remaining conditions. Our results showed that the thermal history affects $\mathrm{CH}$ during the earlyand mid-winter stages, where the colder environment $\left(\mathrm{W}_{\mathrm{N}}\right)$ leads to higher $\mathrm{CH}$ status (lower LT) of trunk vascular tissues. However, this difference was lost about one month before the beginning of spring in trunk phloem, while $\mathrm{CH}$ in xylem was maintained for a longer period until the end of winter (Table 3; SupplFigs. 3-5). Therefore, this late period of the dormant season is, independently of temperatures, the most susceptible to cold events in vineyards. In the particular case of MZA, this stage requires particular attention because it is precisely the period of the year that experiences the highest incidence of Zonda winds that generate conditions of wide thermal amplitude and are generally followed by strong frosts (Caretta et al., 2004) which can produce damage in trunk vascular tissues (Gonzalez Antivilo, 2018).

Despite past efforts to understand the underlying mechanisms of $\mathrm{CH}$ changes through the dormant season, they are still not clear at all, and there is no certainty around what is the main thermal parameter driving this process. Several studies in V. vinifera imply that Tmean of the previous day is the main factor involved (Ferguson et al., 2011, 2014); however, other studies did not find such a relationship (Badulescu and Ernst, 2006). Hubácková (1996) found a high correlation with Tmean but considering a thermal history of 15 days. Their results suggest that
Tmax explains better the changes in $\mathrm{CH}$, whereas no correlation with Tmin was found. Londo and Kovaleski (2017) found that the best correlation with $\mathrm{CH}$ was given using a 7-day thermal history by employing a temperature index calculated using hourly temperatures. In our case, when correlating our three years of measurement of $\mathrm{CH}$ (in both xylem and phloem) with different thermal parameters, we found that Tmax and Tmin were the ones that best explained the changes in $\mathrm{CH}$ when only a single day was considered prior to our simulated freezing event (Fig. 3). However, when more days were considered, the correlation of Tmin with $\mathrm{CH}$ increased considerably (phloem: $\mathrm{r}_{1 \text { day }}=0.51$; $r_{15 \text { day }}=0.78$; xylem: $\left.r_{1 \text { day }}=0.42 ; r_{15 \text { day }}=0.77\right)$ whereas when evaluating Tmax, the increase of days did not improve the explanation of $\mathrm{CH}$ variation. Similar results were found in walnut (Poirier et al., 2010).

\subsection{Physicochemical changes associated with to cold acclimation and deacclimation processes}

Many quantitative and qualitative physiochemical modifications can occur in response to cold. Most plant species accumulate different kinds of compatible solutes such as soluble sugars and amino acids under stress (Guy, 1990; Close, 1997). We attempted to analyze the weight of these components relative to $\mathrm{CH}$ status. We found that TSS are strongly related with $\mathrm{CH}$, whereas WC exhibited a weaker relationship. We did not identify any relationship between $\mathrm{CH}$ and either TFA or starch content.

Soluble sugars constitute some of the most well-known compatible solutes during freezing events, since they are involved in the supercooling process (Chen and Li, 1977; Hamman et al., 1996; Howell, 2000; Badulescu and Ernst, 2006). In V. vinifera, soluble sugars content has been observed to change in concordance with acclimation to low temperatures in buds and canes (Hinesley et al., 1992). Our results suggest that similar responses occur in young grapevine trunks. This means that TSS accumulation is a dynamic and variable process that 
occurs in different tissues and organs of grapevine. Keller (2010) suggested that the soluble sugars reach a peak in accordance with the coldest temperatures during mid-winter. Contrary to the prevailing opinion, TSS were unrelated to $\mathrm{CH}$ in some woody plant species, i.e., high levels of total sugars did not necessarily coincide with increases in CH (Stushnoff et al., 1993). Beck et al. (2004) mentioned that in forest species the sugar content between an acclimated plant and a deacclimated plant can be up to 4-folds different. In our research, we found a close relationship between the TSS content and $\mathrm{CH}$ status during the first two months of winter. In concordance with Beck et al. (2004) the differences found here were close to 4-fold but only in the most contrasting year (Y-3, Fig. 4). However, these differences became weaker through the last part of the dormant season (Fig. 4). This suggests that sugar content varies according to yearly climatic characteristics but also in different stages of the dormant season in the same year.

The tissue WC is also considered a factor that is highly correlated with resistance to cold (Howell, 2000; Poirier et al., 2010). We found some correlation between $\mathrm{CH}$ status and WC (Fig. 5). Several species reduce the water content of their tissues during the dormant season to values similar to our results in order to reduce freezable water (Chen and Li, 1977). This has also been observed in V. vinifera (Parostarchy et al., 1980) and other fruit species (Kang et al., 1997). In fact, Chen and Li (1977) reported that by forcing dehydration for a period of 21 days, tissues can quadruple their resistance to cold.

Regarding amino acids, several studies suggest that they act as compatible solutes in a similar way as soluble sugars, participating in the supercooling process. Among amino acids, proline has been frequently found to increase during stress, and has been described as cryoprotectant in many species (Duncan and Widholm, 1987; Guy, 1990; Ait Barka and Audran, 1997). However, in the present work, although a modulation of the amino acid content was observed throughout the winter due to temperature fluctuations, no clear relationship with $\mathrm{CH}$ could be established.

\subsection{Agroecological regions in the context of climate change}

Most agroclimatic indices are constructed on basis of the growing season period. Much less emphasis has been given on estimating indices for the dormant season (for a recent example see Badr et al., 2018). Such indices could be used to measure the sustainability of a variety under inclement weather during winter and at the time of bud burst (Mosedale et al., 2015). Deis et al. (2015) published several ecological indices for the winter using 10 years of thermal records in MZA (2001-2010) and demonstrating large differences among the different oases (SupplFig. 1c). Moreover, our results show that there are marked differences among years for the same site.

One of the aims of this research was to artificially alter natural agroclimatic conditions using heating systems to emulate warmer agroecological scenarios (Fig. 2, Table 1, SupplFig. 1) as is expected for MZA (Deis et al., 2015). In this way, our artificial system $\left(\mathrm{W}_{\mathrm{W}}\right)$ was capable to increase $\Sigma$ Tmin compared with natural conditions $\left(\mathrm{W}_{\mathrm{N}}\right)$ for each year $(20,130$ and $30 \%$ increase in Y-1, Y-2 and Y-3 respectively). It should be noted that in Y-3, our $\Sigma$ Tmin results were higher in $\mathrm{W}_{\mathrm{N}}$ and $\mathrm{W}_{\mathrm{W}}$ than those reported historically in the warmest region of MZA (East oases; SupplFig2 C; Deis et al., 2015).

An increase in late-winter temperature can advance the time of bud burst, increasing the risk of spring frost damage (Mosedale et al., 2015). Variations in the average date of bud burst have been reported among the different productive oases of MZA, first bud burst the North oases (Sept-22), followed by the East oases (Sept-25) and later in the Central oases (Oct-6) (DACC, 2013). In each year in this work, the $\mathrm{W}_{\mathrm{W}}$ treatment induced an early bud burst with respect to $\mathrm{W}_{\mathrm{N}}$. The difference was 17 days in the coldest year (Y-2) and 32 days in the warmest year (Y-3) (Table 2).

In the context of climate change, weather alterations are expected to increase the Tmin, decrease the number of cold events and increase the variation of temperatures during winter and the occurrence of unseasonable and extreme warm and cold events (Solomon et al., 2007; Gu et al., 2008; Stocker et al., 2013; Londo and Kovaleski, 2017). These changes might have consequences in crops, such as an extension of the growing season by a delay in leaf fall (Hänninen, 1991; Saxe et al., 2001). Also, this may accelerate bud burst, leaving new shoots more susceptible to late frost (Mosedale et al., 2015). In contrast, frost reduction does not necessarily reduce the risk of frost damage. Instead, it could remain the same or even become greater (Cannell and Smith, 1986; Meehl, 2000; Londo and Kovaleski, 2017). For deciduous forests it was demonstrated that alternating warm and cold waves in spring are more harmful to plants than a consistently cold spring (Gu et al., 2008). Our study of $\mathrm{W}_{\mathrm{W}}$ might demonstrate how the same variety reaches a lesser acclimation level and higher susceptibility to freeze damage (Table 3).

It is common for the same grape cultivar to be grown in different regions, and this situation could lead to different $\mathrm{CH}$ status even over a distance of a few kilometers. In MZA, as in several other regions around the world, the frontier of grape production has been extended to new regions without a refined knowledge of the influence of the agrometeorological characteristics on $\mathrm{CH}$ of each cultivar.

\section{Conclusions}

Our results obtained from 3-years of assays in plants of $V$. vinifera subjected to contrasting warm winter environments revealed that temperature drives differences in $\mathrm{CH}$ status in plants. Both thermal parameters showed a significant positive correlation with $\mathrm{CH}$; however, a 15-days thermal history of Tmin was found to be the main driver of acclimation status. Yet this was true only in the early- and mid-winter, whereas in the last part of the winter, no treatment effect was registered at least in the trunk phloem. On other hand, when the association of various compounds related to $\mathrm{CH}$ was analyzed, we found that sugars have the greatest weight, followed by water content. The artificially created environments in this work could perfectly fit to predicted scenarios of climate change, and in this context grapevines would be more exposed to cold damage than at present.

\section{Acknowledgements}

This work was supported by Agencia Nacional de Promoción Científica y Tecnológica, Argentina (ANPCyT) - Universidad Nacional de Cuyo (UNCuyo) [PRH, 2007] and Concejo Nacional de Investigaciones Científicas y Técnicas (CONICET) [PhD fellowship, 2016-2018]. We thank the staff of Vegetal Physiology Department and Biological Chemistry of Agronomy Faculty of UNCuyo Mendoza (especially Bruno Cavagnaro and Emiliano Malovini); Institute of Agricultural Biology of Mendoza, IBAM CONICET/FCA-UNCuyo (especially Ruben Bottini, Patrícia Piccoli, Federico Berli, and Maria Victoria Salomón); Viticulture Laboratory of IAREC in Washington State (especially Lynn Mills, John Ferguson, and Allan Kawakami), Statistical Department of UNC Córdoba (especially Mónica Balzarini and Mariano Córdoba), INTA EEA Mendoza Ecophysiology and Viticulture Department (especially Jorge Perez Peña, Eugenia Galat Giorgi, Jorge Prieto and Dante Gamboa) and IANIGLA CCT-Mendoza (especially Federico Gonzalez) for sharing their knowledge, equipment and technical support. Moreover, we thank all the students that participated in this research. A special thank you to Mercier Plant Nursery that kindly supplied the plant material for this research and to Floralis ${ }^{\circledR}$ laboratory for sharing their infrastructure and equipment.

\section{Appendix A. Supplementary data}

Supplementary material related to this article can be found, in the online version, at doi:https://doi.org/10.1016/j.agrformet.2018.07. 017. 


\section{References}

Ait Barka, E., Audran, J.C., 1997. Response of champenoise grapevine to low temperatures: changes of shoot and bud proline concentrations in response to low temperatures and correlations with freezing tolerance. J. Hortic. Sci. 72 (4), 577-582. https://doi.org/10.1080/14620316.1997.11515546.

Andrews, P.K., Sandidge, C.R., Toyama, T.K., 1984. Deep supercooling of dormant and deacclimating Vitis buds. Am. J. Enol. Vitic. 35 (3), 175-177.

Aruani, A.C., 2010. Cambio climático y vitivinicultura. Estrategias de adaptación en Argentina. Instituto Nacional de Vitivinicultura 26 agosto 2010.

Aslamarz, A.A., Vahdati, K., Rahemi, M., Hassani, D., Leslie, C., 2010. Supercooling and cold-hardiness of acclimated and deacclimated buds and stems of Persian walnut cultivars and selections. HortScience 45 (11), 1662-1667.

Badr, G., Hoogenboom, G., Moyer, M., Keller, M., Rupp, R., Davenport, J., 2018. Spatial suitability assessment for vineyard site selection based on fuzzy logic. Precis. Agric 1-22. https://doi.org/10.1007/s11119-018-9572-7.

Badulescu, R., Ernst, M., 2006. Changes of temperature exotherms and soluble sugars in grapevine (Vitis vinifera L.) buds during winter. J. Appl. Bot. Food Qual. 80 (2), 165-170.

Beck, E.H., Heim, R., Hansen, J., 2004. Plant resistance to cold stress: mechanisms and environmental signals triggering frost hardening and dehardening. J. Biosci. 29 (4), 449-459.

Burke, M.J., Gusta, L.V., Quamme, H.A., Weiser, C.J., Li, P.H., 1976. Freezing and injury in plants. Annu. Rev. Plant Physiol. 27, 507-528. https://doi.org/10.1146/annurev. pp.27.060176.002451.

Cannell, M.G.R., Smith, R.I., 1986. Climatic warming, spring budburst and frost damage on trees. J. Appl. Ecol. 23, 177-191. https://doi.org/10.2307/2403090.

Caretta, A., Ortega, A., Ortíz Maldonado, A., 2004. Probability of damage to vines, fruit and olive trees blossom by Zonda wind Mendoza, Argentina. Rev. FCA UNCuyo 36, 49-58.

Chen, P.M., Li, P.H., 1977. Induction of frost hardiness in stem cortical tissues of Cornus stolonifera Michx. By water stress. II. Biochemical changes. Plant Physiol. 59, 240-243. https://doi.org/10.1104/pp.59.2.240.

Close, T.J., 1997. Dehydrins: a commonalty in the response of plants to dehydration and low temperature. Physiol Plantarum. 100 (2), 291-296. https://doi.org/10.1111/j. 1399-3054.1997.tb04785.x.

Cragin, J., Serpe, M., Keller, M., Shellie, K., 2017. Dormancy and cold hardiness transitions in wine grape cultivars chardonnay and cabernet sauvignon. Am J Enol Vitic. 68, 195-202. https://doi.org/10.5344/ajev.2016.16078.

DACC, Agricultural Climate Contingencies Department, 2013. Informe de fenología de la vid, campaña 2012-2013. Retrived from. www.contingencias.mendoza.gov.ar.

Deis, L., de Rosas, M., Malovini, E., Cavagnaro, M., Cavagnaro, J.B., 2015. Impacto de cambio climático en Mendoza: Variación climática en los últimos 50 años. Mirada desde la fisiología de la vid. Rev. FCA UNCuyo 47, 67-92.

Di Rienzo, J.A., Guzman, A.W., Casanoves, F., 2002. A multiple comparisons method based on the distribution of the root node distance of a binary tree. J. Agric. Biol. Environ. Stat. 7, 129-142. https://doi.org/10.1198/10857110260141193.

Di Rienzo, J.A., Casanoves, F., Balzarini, M.G., Gonzalez, L., Tablada, M., Robledo, C.W. 2017. InfoStat Versión 2017. Grupo InfoStat, FCA, Universidad Nacional de Córdoba, Argentina. www.infostat.com.ar.

Duncan, D.R., Widholm, J.M., 1987. Proline accumulation and its implication in cold tolerance of regenerable maize callus. Plant Physiol. 83 (3), 703-708.

Fennell, A., 2004. Freezing tolerance and injury in grapevines. J. Crop. Improv. 10 (1-2), 201-202. https://doi.org/10.1300/J411v10n01. 35

Fennell, A., Hoover, E., 1991. Photoperiod influences growth, bud dormancy, and cold acclimation in Vitis labruscana and V. Riparia. J. Am. Soc. Hortic. Sci. 116 (2), 270-273.

Ferguson, J.C., Tarara, J.M., Mills, L.J., Grove, G.G., Keller, M., 2011. Dynamic thermal time model of cold hardiness for dormant grapevine buds. Ann. Bot. 107, 389-396. https://doi.org/10.1093/aob/mcq263.

Ferguson, J.C., Moyer, M.M., Mills, L.J., Hoogenboom, G., Keller, M., 2014. Modeling dormant bud cold hardiness and budbreak in twenty-three Vitis genotypes reveals variation by region of origin. Am. J. Enol. Vitic. 65, 57-71. https://doi.org/10.5344/ ajev.2013.13098

González, G., Nazrala, J., Beltrán, M., Alberto, M., 2009. Caracterización de uvas para vinificar en diferentes regiones de Mendoza (Argentina). Rev. FCA UNCuyo 41 (1), 165-175.

Gonzalez Antivilo, F., 2018. Caracterización de la respuesta anatómica y efecto de la modulación de la temperatura sobre la fisiología de resistencia al frío de Vitis vinifera durante la estación de dormición. Universidad Nacional de Cuyo, Mendoza, Mendoza, Argentina Ph D Thesis.

Gonzalez Antivilo, F., Paz, R.C., Keller, M., Borgo, R., Tognetti, J., Roig Juñent, F., 2017. Macro-and microclimate conditions may alter grapevine deacclimation: variation in thermal amplitude in two contrasting wine regions from North and South America. Int. J. Biometeorol. 61 (12), 2033-2045. https://doi.org/10.1007/s00484-017 1400-7.

Gu, L., Hanson, P., Mac Post, W., Kaiser, D., Yang, B., Nemani, R., Meyers, T., 2008. The 2007 eastern US spring freeze: increased cold damage in a warming world. Bioscience 58 (3), 253-262. https://doi.org/10.1641/B580311.

Guy, C.L., 1990. Cold acclimation and freezing stress tolerance: role of protein metabolism. Annu. Rev. Plant Physiol. Plant Mol. Biol. 41, 187-223. https://doi.org/10. 1146/annurev.pp.41.060190.001155.

Hamman, R.A., Dami, I.E., Walsh, T.M., Stushnoff, C., 1996. Seasonal carbohydrate changes and cold hardiness of Chardonnay and Riesling grapevines. Am. J. Enol.
Vitic. $47,31-36$

Hänninen, H., 1991. Does climatic warming increase the risk of frost damage in northern tress? Plant Cell Environ. 14, 449-454. https://doi.org/10.1111/j.1365-3040.1991. tb01514.x.

Hinesley, L.E., Pharr, D.M., Snelling, L.K., Funderburk, S.R., 1992. Foliar raffinose and sucrose in four conifer species: relationship to seasonal temperature. J. Am. Soc. Hortic. Sci. 117 (5), 852-855.

Howell, G.S., 2000. Grapevine cold hardiness: mechanisms of cold acclimation, mid winter hardiness maintenance, and spring deacclimation. In: Washington, June. Proceedings of the American Society of Enology and Viticulture Annual Meeting, Seattle Vol. 19. pp. 23

Hubácková, M., 1996. Dependence of grapevine bud cold hardiness on fluctuations in winter temperatures. Am. J. Enol. Vitic. 47, 100-102.

INV, 2016. Análisis de la evolución de la superficie 2000-2016. Retrived from. Vitiviniculture National Institute. www.inv.gob.ar.

Kang, S.K., Motosugi, H., Yonemori, K., Sugiura, A., 1997. Exothermic characteristics of dormant buds of persimmon (Diospyros kaki Thunb.) in relation to cold hardiness. HortScience 32 (5), 840-843.

Keller, M., 2010. The Science of Grapevines: Anatomy and Physiology. Elsevier: Academic Press, Burlington, MA, USA.

Levitt, J., 1980. Responses of plants to environmental stresses, 2nd ed. Chilling, Freezing and High Temperature Stresses Vol. 1 Academic Press, New York 497 p.

Londo, J.P., Kovaleski, A.P., 2017. Characterization of wild north american grapevine cold hardiness using differential thermal analysis. Am J Enol Vitic. 68, 203-212. https://doi.org/10.5344/ajev.2016.16090.

McCready, R.M., Guggolz, J., Silviera, V., Owens, H.S., 1950. Determination of starch and amylose in vegetables. Anal. Chem. 22 (9), 1156-1158.

Meehl, G.A., 2000. An introduction to trends in extreme weather and climate events: observations, socioeconomic impacts, terrestrial ecological impacts, and model projections. Bull. Am. Meteorol. Soc. 81, 413-416. https://doi.org/10.1175/15200477(2000)081 < 0413:AITTIE > 2.3.CO;2.

Mills, L.J., Ferguson, J.C., Keller, M., 2006. Cold-hardiness evaluation of grapevine buds and cane tissues. Am. J. Enol. Vitic. 57, 194-200.

Moran, R.E., Sun, Y., Geng, F., Zhang, D., Fazio, G., 2011. Cold temperature tolerance of trunk and root tissues in one-or two-year-old apple rootstocks. HortScience 46 (11), 1460-1464.

Mosedale, J.R., Wilson, R.J., Maclean, I.M., 2015. Climate change and crop exposure to adverse weather: changes to frost risk and grapevine flowering conditions. PloS one 10 (10), e0141218. https://doi.org/10.1371/journal.pone.0141218.

Norte, F., Simonelli, S., 2016. Validation of a statistical forecast model for Zonda wind in West Argentina based on the vertical atmospheric structure. Atmos. Clim. Sci. 6 (1), 35-50. https://doi.org/10.4236/acs.2016.61004.

Parostarchy, J.H., Meiering, A.G., Peterson, R.L., Hostetter, G., Neff, A., 1980. Mechanical winter injury in grapevine trunks. Am. J. Enol. Vitic. 31 (3), 227-232.

Pierquet, P., Stushnoff, C., 1980. Relationship of low temperature exotherms to cold injury in Vitis riparia Michx. Am. J. Enol. Viticult. 31 (1), 1-6.

Poirier, M., Lacointe, A., Améglio, T., 2010. A semi-physiological model of cold hardening and dehardening in walnut stem. Tree Physiol. 30, 1555-1569. https://doi.org/10. 1093/treephys/tpq087.

Proebsting, E.L., Ahmedullah, M., Brummund, V.P., 1980. Seasonal changes in low temperature resistance of grape buds. Am. J. Enol. Vitic. 31 (4), 329-336.

Saxe, H., Cannell, M.G.R., Johnsen, B., Ryan, M.G., Vourlitis, G., 2001. Tree and forest functioning in response to global warming. New Phytol. 149, 369-399. https://doi. org/10.1046/j.1469-8137.2001.00057.x.

Schnabel, B.J., Wample, R.L., 1978. Dormancy and cold hardiness in Vitis vinifera L. cv. White Riesling as influenced by photoperiod and temperature. Am. J. Enol. Vitic. 38, 265-272.

Shaulis, N., 1971. Vine hardiness a part of the problem of hardiness to cold in NY vineyards. Proc. NY State Hortic. Soc Vol. 116, 158-166.

Solomon, S., Qin, D., Manning, M., Chen, Z., Marquis, M., Averyt, K.B., Tignor, M., Miller, H.L., 2007. Climate Change 2007: The Physical Science Basis. Contribution of Working Group I to the Fourth Assessment Report of the Intergovernmental Panel on Climate Change. Cambridge University Press, New York.

Stocker, T.F., Qin, D., Plattner, G.K., Tignor, M., Allen, S.K., Bostarchung, J., Midgley, B.M., 2013. IPCC 2013: climate change 2013: the physical science basis. Contribution of Working Group I to the Fifth Assessment Report of the Intergovernmental Panel on Climate Change.

Stushnoff, C., Remmele Jr, R.L., Esensee, V., McNeil, M., 1993. Low temperature induced biochemical mechanisms: implications for cold acclimation and de-acclimation. In: Jacson, M.B., Black, C.R. (Eds.), Interacting Stresses on Plants in a Changing Climate (Vol.116) NATO ASI Series. Springer-Verlag, pp. pp647-657.

Vitra, A., Lenz, A., Vitasse, Y., 2017. Frost hardening and dehardening potential in temperate trees from winter to budburst. New Phytol. 216.1, 113-123. https://doi. org/10.1111/nph.14698.

Weiser, C.J., 1970. Cold resistance and injury in woody plants. Science 169, 1269-1278. https://doi.org/10.1126/science.169.3952.1269.

Yemm, E.W., Cocking, E.C., 1955. The determination of amino acids with ninhydrin. Analyst 80, 209-213.

Yemm, E.W., Willis, A.J., 1954. The estimation of carbohydrates in plant extracts by anthrone. J. Biochem. 57, 508-514.

Zabadal, T.J., Dami, I.E., Goffinet, M.C., Martinson, T.E., Chien, M.L., 2007. ). Winter Injury to Grapevines and Methods of Protection. Michigan State University Extension, East Lansing. 